\title{
Validation of the ECOS-16 Questionnaire in Koreans with Osteoporosis
}

\author{
Jung Sub Lee ${ }^{1}$, Seung Min Son ${ }^{1}$, Tae Sik Goh ${ }^{1}$, Taek Hoon $\mathrm{Kim}^{1}$, Eun Yeong Noh $^{2}$ \\ ${ }^{1}$ Medical Research Institute, Department of Orthopaedic Surgery, Pusan National University School of Medicine, Busan, Korea \\ ${ }^{2}$ Medical Research Institute, Department of General Affairs, Pusan National University Hospital, Busan, Korea
}

\begin{abstract}
Study Design: Prospective study.
Purpose: To evaluate the reliability and validity of the adapted Korean version of the Quality of Life Questionnaire of the European Foundation for Osteoporosis (ECOS-16).

Overview of Literature: The validity of the Korean version of ECOS-16 has not been completely demonstrated.

Methods: Translation/retranslation of the English version of ECOS-16, and full cross-cultural adaptation were performed. The Korean version of a visual analog scale measure of pain, and the Korean versions of ECOS-16 and of the previously validated short form-36 (SF-36) were mailed to 158 consecutive patients with osteoporosis. Factor analysis and reliability assessment using kappa statistics of agreement for each item, intraclass correlation coefficient, and Cronbach's a were done. Construct validity was evaluated by comparing responses to ECOS-16 with responses to SF-36 using Pearson's correlation coefficient.

Results: Factor analysis extracted three factors. All items had a kappa statistics of agreement $>0.6$. The ECOS-16 showed good test/ re-test reliability (0.8469) and internal consistency of Cronbach's a (0.897). The Korean version of ECOS-16 showed significant correlation with SF-36 total scores and with single SF-36 domains scores.

Conclusions: The adapted Korean version of the ECOS-16 was successfully translated and showed acceptable measurement properties. It is considered suitable for outcome assessments in Korean patients with osteoporosis.
\end{abstract}

Keywords: Osteoporosis; ECOS-16

\section{Introduction}

Osteoporosis is the most prevalent metabolic bone disease in older people. It has been estimated $30 \%-50 \%$ of women and $15 \%-30 \%$ of men will suffer an osteoporotic fracture [1]. Vertebral fracture is one of the most common osteoporotic fractures; it is a major public health problem that affects millions of people worldwide [2,3]. In the Korean population, the standardized prevalence for vertebral fractures using the age distribution has been reported to be $12.6 \%$ in women and $8.8 \%$ in men [4].

Vertebral fractures are associated with significant morbidity in terms of physical and psychological functioning and reduced health-related quality of life (HRQoL) [510]. Furthermore, the sum of physical, social and mental functioning has played an important role in clinical studies, particularly as an outcome measure in clinical trials $[11,12]$.

Several generic instruments have been developed for measuring QoL, such as short form-36, the Sickness

Received Jan 10, 2016; Revised Feb 11, 2016; Accepted Mar 1, 2016

Corresponding author: Jung Sub Lee

Medical Research Institute, Department of Orthopaedic Surgery, Pusan National University School of Medicine,

179 Gudeok-ro, Seo-gu, Busan 49241, Korea

Tel: +82-51-240-7248, Fax: +82-51-247-8395, E-mail: jungsublee@pusan.ac.kr 
Impact Profile and the Nottingham Health Profile [1315]. These generic instruments give a general estimate of health and are not specific for any disease. Thus, several disease-specific questionnaires with good validity and reliability have been designed to assess QoL in patients with osteoporosis. These include the Quality of Life Questionnaire of the European Foundation for Osteoporosis (QUALEFFO-41) [7], the Osteoporosis Quality of Life Questionnaire (OQLQ) [16], mini-OQLQ, ECOS-16 [17], the Osteoporosis Assessment Questionnaire (OPAQ), and the Osteoporosis Functional Disability Questionnaire (OFDQ).

ECOS-16 was developed to evaluate quality of life in postmenopausal osteoporotic patients based on the osteoporosis specific quality of life instruments QUALEFFO [7] and OQLQ [16]. ECOS-16 contains 12 items from QUALEFFO and four items from OQLQ. The 16 items in ECOS-16 are divided in the four dimensions of physical functioning, pain, fear of illness and psychosocial function. Five response options are offered per item with scores varying between 1 and 5 points, where 5 represents the worst QoL score [17].

This questionnaire has been translated into different languages and has been judged valid. These kinds of questionnaires must be translated into the respective local languages and must also be culturally adapted. The objectives of this study were to translate a culturally adapted version of the ECOS-16 questionnaire into the Korean language and to validate this version in Korean patients.

\section{Materials and Methods}

This study was approved by the ethics committee of our institute.

The translation procedure in this study followed the guidelines for the cross-cultural adaptation of self-report measures [18]. The translation procedure was conducted in three stages: forward translation, back translation, and expert committee discussion. In addition, a pilot study was performed to determine whether the prefinal version could be understood correctly by Korean osteoporosis or osteopenia patients. The final version resulting from expert committee discussion was tested for validity and reliability using the Korean version of the short form-36 (SF36) [19].

The forward translation was completed by two native Korean translators. The first translator was an orthopaedic surgeon and the other was a professional translator with no medical background who was not initially informed of the purpose of the translation. The two translators' versions and the original version were compared and discussed by the two translators and another orthopaedic surgeon, until agreement was reached.

The back translation was completed independently by two bilingual translators whose native language was English. Both of these translators lacked a medical background and were not informed or aware of the prior translation procedures.

All versions of the translation as well as the original were discussed by the four translators and an expert committee comprised of three bilingual experts, two orthopaedic surgeons, and a Korean translation expert. This committee discussed the translation procedure and results until consensus was reached regarding discrepancies. The result was the prefinal version of the ECOS-16 questionnaire.

This prefinal version was administered to 40 Koreanspeaking female osteoporosis or osteopenia patients, who were questioned regarding their understanding of the questionnaire items and their responses. The mean age was 61.3 years (range, $48-76$ years). The interviewer was asked to document any problems that occurred during administration of the questionnaire. In addition, at the end of all interviews the patients were asked to provide comments about the questionnaire and to identify any words that were difficult to understand. All 40 patients correctly understood the questionnaire. The final form of the Korean version of the ECOS-16 questionnaire was determined by the expert committee, with the participation of all translators and a consensus was achieved (Appendix 1).

A total of 158 consecutive patients with osteoporosis were included in this study. Eighty one (51.3\%) had at least one morphometrically defined vertebral fracture and, as the control, 77 (48.7\%) were osteoporosis or osteopenia patients without a fracture were included. The World Health Organization classification for osteoporosis was used throughout the study. Patients with any notable physical disorder, metabolic bone disease, or malignancy were excluded. Osteoporotic patients with a clinical (symptomatic) vertebral fracture were also excluded. Control subjects were required to have no apparent kyphosis and no morphometric vertebral fracture. Lumbar spine magnetic resonance imaging (MRI) was performed with all subjects to find a symptomatic vertebral fracture. 
Lumbar spinal bone mineral density (LSBMD) and femoral neck BMD (FNBMD) of the non-dominant proximal femur were measured by dual-energy X-ray absorptiometry (DEXA) using a XR-36 apparatus (Norland Co., Fort Atkinson, WI, USA). LSBMD was measured in L1 to L4 in the anterior-posterior view. This study defined osteoporosis and osteopenia as BMD lowest T-score at any site $\leq-2.5$ and -1.50 to -2.49 , respectively, at the lumbar spine or hip.

The Korean version of the visual analog scale (VAS) measure of pain, ECOS-16, and SF-36 were mailed to 158 consecutive patients (127 females, 31 males) with osteoporosis or osteopenia. First mailing contained a consent form; description of the study; Korean versions of VAS measure for pain, ECOS-16, and SF-36; and an addressed and stamped return envelope. One hundred and twenty one patients (97 females, 24 males) responded to the first set of questionnaires. One hundred two ( 80 females, 22 males) of the first-time respondents returned the second survey. The average age of the 102 patients was 63.5 years (range, 51-79 years) at the time of survey, and the average time between first and second mailings was 2 weeks.

Test-retest reliability was measured by comparing responses to first and second ECOS-16 assessments. Reliability was assessed using kappa statistics of agreement for each items of ECOS-16 and by calculating the intraclass correlation coefficient (ICC2, ICC1). Cronbach's a was used to evaluate internal consistency. Factor analysis used was to determine the dimensionality of the ECOS-16 items. An item loading on each factor $\geq 0.4$ was considered satisfactory. Individual domain scores were calculated by summing item scores, which were then linearly transformed to a $0-100$ scale, where 100 represented poor health. Floor and ceiling effects were assessed by calculating the percentages of subjects with lowest or highest possible domain scores, respectively. Concurrent and construct validity were evaluated by comparing the responses of ECOS-16 with the results of VAS and responses of SF-36 using Pearson's correlation coefficient. The distributions of floor and ceiling effects of the Korean

Table 1. The demographic characteristics of the study population

\section{Characteristic}

First assessment Second assessment

Sex (n)

\begin{tabular}{|c|c|c|}
\hline Female & 97 & 80 \\
\hline Male & 24 & 22 \\
\hline \multicolumn{3}{|l|}{ Education (n) } \\
\hline Elementary school & 65 & 58 \\
\hline Middle school & 31 & 25 \\
\hline High school & 19 & 13 \\
\hline University & 6 & 6 \\
\hline \multicolumn{3}{|l|}{ Profession (n) } \\
\hline White collar & 5 & 5 \\
\hline Blue collar & 19 & 19 \\
\hline Intermediate level & 16 & 15 \\
\hline Retired & 14 & 10 \\
\hline Housewife & 30 & 26 \\
\hline Unemployed & 37 & 27 \\
\hline Time period between first and second survey (day) & & 14.0 (range, 8-22) \\
\hline \multicolumn{3}{|l|}{ Osteoporosis (po) or osteopenia (pe) (n) } \\
\hline Fracture (po/pe)/Control (po/pe) & $65(19 / 46) / 56(15 / 41)$ & $54(15 / 39) / 48(12 / 36)$ \\
\hline ECOS-16 (mean $\pm S D)$ & $33.7 \pm 13.3$ & $34.4 \pm 12.8$ \\
\hline Short form-36 (mean $\pm S D)$ & $48.1 \pm 19.7$ & $47.3 \pm 20.1$ \\
\hline Visual analog scale (mean $\pm S D)$ & $44 \pm 26$ & $44 \pm 25$ \\
\hline
\end{tabular}

SD, standard deviation. 
ECOS- 16 were determined by calculating the proportions of individuals with lowest and highest scores, respectively. The statistical analysis was performed using SPSS ver. 16.0 (SPSS Inc., Chicago, IL, USA).

\section{Results}

One hundred fifty eight native Korean-speaking patients with osteoporosis or osteopenia were enrolled. One hundred and two patients completed the second assessment. Table 1 summarizes the demographic characteristics of the study population.

Mean scores on ECOS-16 and SF-36 for fracture cases and controls are shown in Table 2. Subjects with a vertebral fracture showed significant impairment of HRQoL on the ECOS-16 compared with controls. Similar results

Table 2. Scores of the ECOS-16 and the SF-36 domain

\begin{tabular}{|c|c|c|c|}
\hline Domain & $\begin{array}{c}\text { Control } \\
\text { (mean } \pm \text { SD) }\end{array}$ & $\begin{array}{c}\text { Fracture } \\
\text { (mean } \pm \text { SD) }\end{array}$ & $p$-value \\
\hline \multicolumn{4}{|l|}{ ECOS-16 } \\
\hline Pain & $34.4 \pm 14.3$ & $49.2 \pm 13.8$ & $<0.001$ \\
\hline Physical function & $25.4 \pm 15.9$ & $33.8 \pm 15.2$ & 0.008 \\
\hline Mental function & $33.9 \pm 10.0$ & $42.2 \pm 10.5$ & 0.001 \\
\hline ECOS-16 total & $29.7 \pm 12.0$ & $39.1 \pm 11.7$ & $<0.001$ \\
\hline \multicolumn{4}{|l|}{ SF-36 } \\
\hline Bodily pain & $48.5 \pm 22.9$ & $34.9 \pm 23.7$ & 0.004 \\
\hline Physical function & $54.0 \pm 33.6$ & $44.5 \pm 30.1$ & 0.126 \\
\hline Mental health & $56.4 \pm 17.8$ & $57.4 \pm 18.2$ & 0.783 \\
\hline Mental component score & $54.3 \pm 19.0$ & $49.8 \pm 18.3$ & 0.227 \\
\hline Physical component score & $49.4 \pm 22.4$ & $38.8 \pm 18.3$ & 0.010 \\
\hline
\end{tabular}

SF-36, short form-36; SD, standard deviation.

Table 3. Factor analysis

\begin{tabular}{|c|c|c|c|}
\hline Item & Pain & Physical function & Mental function \\
\hline How often have you had back pain in the last week? & 0.850 & & \\
\hline How severe is your back pain? & 0.817 & & \\
\hline $\begin{array}{l}\text { How much distress or discomfort have you had because it has been painful } \\
\text { to stand for a long time? }\end{array}$ & 0.726 & & \\
\hline How much distress or discomfort have you had due to pain from bending? & 0.588 & & \\
\hline Has the back pain disturbed your sleep in the last week? & 0.572 & & \\
\hline How difficult has it been for you to carry out the household activities? & & 0.714 & \\
\hline Can you climb stairs to the next floor of a house? & & 0.651 & \\
\hline Do you have problems with dressing? & & 0.741 & \\
\hline How difficult has it been for you to bend? & & 0.857 & \\
\hline How much has your walking been limited? & & 0.849 & \\
\hline How difficult has it been for you to visit friends or relatives? & & & 0.601 \\
\hline Do you feel downhearted? & & & 0.753 \\
\hline Are you hopeful about your future? & & & 0.617 \\
\hline Do you feel frustrated? & & & 0.515 \\
\hline Are you afraid of falling? & & & 0.543 \\
\hline Are you afraid of getting a fracture? & & & 0.499 \\
\hline
\end{tabular}


were also observed for SF-36.

Factor analysis of the Korean ECOS 16 revealed a threefactor structure that explained $64.7 \%$ of total variance and extracted three factors with eigenvalues superior to 1 (Table 3). The Korean ECOS-16 consisted of three domains: pain, physical function, and mental function.

All items of the Korean ECOS-16 had kappa values for agreement $>0.6$ (range 0.63 to 0.91 ). The ICC of the test/re-test reliability was 0.8469 for the 16 items of the Korean ECOS-16, 0.8777 for the pain domain, 0.8169 for the physical function domain, and 0.7668 for the mental function domain (Table 4). Internal consistency was very good, with Cronbach's a (Table 5).

Concurrent validity was evaluated by comparing responses to the Korean ECOS-16 with VAS results using Pearson correlation coefficients. Positive correlations were found between the Korean ECOS-16 and VAS ( $r=0.7161$;

Table 4. Test-retest reproducibility as determined by intraclass correlation coefficient $(n=102)$

\begin{tabular}{lc} 
Ouestionnaire & ICC $(95 \% \mathrm{CI})$ \\
ECOS-16 total & $0.8469(0.8139-0.8741)$ \\
\hline ECOS-16 pain & $0.8777(0.8423-0.9114)$ \\
ECOS-16 physical fuction & $0.8169(0.7861-0.8812)$ \\
\hline ECOS-16 mental function & $0.7668(0.7339-0.8417)$ \\
\hline
\end{tabular}

ICC, intraclass correlation coefficient; $\mathrm{Cl}$, confidence interval.

Table 5. Internal consistency by Cronbach's alpha ( $n=121)$

\begin{tabular}{lc} 
ECOS-16 & Cronbach's alpha \\
\hline Total & 0.897 \\
Pain & 0.913 \\
Physical function & 0.898 \\
Mental function & 0.743 \\
\hline
\end{tabular}

$p<0.001$ for the 16 items of the Korean ECOS-16, $r=0.7216$; $p<0.001$ for the pain domain, $r=0.6216 ; p<0.001$ for the physical function domain and $r=0.5887 ; p<0.001$ for the mental function domain). Construct validity based on comparisons with SF-36 questionnaire is shown in Table 6. When we investigated the relationship between Korean ECOS-16 and SF-36 scores, we obtained $r$ of -0.7643 . Convergent validity for the Korean ECOS-16 was demonstrated by moderate to high correlations $(r=0.5-0.8)$. Strong correlations were observed between ECOS-16 pain scores and SF-36 bodily pain scores $(r=-0.665)$, ECOS-16 physical function scores and SF-36 physical functioning scores $(r=-0.713)$, and ECOS-16 mental function score and SF-36 mental health score $(r=-0.536)$. Correlation coefficients between the domain scores of Korean ECOS16 and other domain scores of SF-36 were relatively weak $(r<0.5)$, indicating adequate divergent validity. No ceiling or floor effects were observed for the Korean ECOS-16. The worst ECOS- 16 score was 63.8 in two patients and the best was 14.7 in one patient.

\section{Discussion}

The objective of this study was to produce a Korean version of ECOS- 16 by translation and adaption. The Korean version of ECOS-16 was clearly understood by and easily administered to patients. The results indicate that the Korean version of the ECOS-16 is a reliable and valid instrument for measuring outcomes in Korean patients with osteoporosis or osteopenia, with reliability levels similar to those of the original [17], Turkish [20], and Italian [21] versions.

Regarding factor analysis, although the original and Italian versions have a four-factor structure [17,21], this study revealed three-factor solutions for the ECOS16. The Turkish study did not perform factor analysis.

Table 6. Pearson correlation coefficient of the ECOS-16 with the SF-36

\begin{tabular}{llc} 
ECOS-16 domain & \multicolumn{1}{c}{ SF-36 domain } & Correlation coefficient \\
Pain & Bodily pain & -0.665 \\
Physical function & Physical function & -0.713 \\
Mental function & Mental health & -0.536 \\
ECOS-16 total & Mental component score & -0.416 \\
ECOS-16 total & Physical component score & -0.593 \\
\hline
\end{tabular}

All correlations are significant at the 0.001 level.

SF-36, short form-36. 
Regarding internal consistency, Salaffi et al. [21] reported that the internal consistencies of ECOS-16 subscales were generally good with Cronbach's alpha values ranging from 0.81-0.89. Cronbach's alpha was 0.87 for ECOS-16 PCS (physical component score), and 0.84 for ECOS-16 MCS (mental component score). The Cronbach's a value of ECOS-16 obtained from this study was 0.897 , and Cronbach's $\alpha$ value of the pain, physical function, and mental function domains was $0.913,0.898$, and 0.743 , respectively, which are similar to those reported by other studies $[17,20,21]$. These results show that this translated version is reliable and has low standard errors of measurement.

The reliabilities of functional status questionnaires can be measured using an interval of 1 to 2 weeks between assessments, because during this time clinical status is unlikely to change appreciably in patients with chronic pain in the absence of specific intervention. In the present study, we mailed the Korean version of VAS for pain, ECOS-16, and SF-36 to 158 osteoporosis or osteopenia patients. The reproducibilities of its 16 items were satisfactory with kappa values of agreement exceeding 0.6. Moreover, agreement between items was good; the ICC of 0.897 indicates the Korean version of ECOS-16 has good reliability.

Our analysis of concurrent validity showed a positive correlation between the Korean version of ECOS-16 and VAS. Furthermore, regarding construct validity, we expected ECOS-16 would show correlations with healthrelated QoL scales. Therefore, we analyzed construct validity by comparing ECOS- 16 total scores to SF-36 total score; a high correlation was found $(p<0.001)$. We also compared the total scores of ECOS- 16 and three subscales to each domain of SF-36. According to the meanings of the subscales, the correlations between the pain domain of ECOS-16 and the bodily pain domain of SF-36 $(r=-0.665)$, between the physical function domain of ECOS-16 and the physical functioning domain of SF-36 $(r=-0.713)$, and between mental function domain of ECOS-16 and mental health domain of SF-36 $(r=-0.536)$ were stronger than other functional domains of the SF- 36 .

Before interpreting the results of the current study, several limitations must be considered. First, the number of subjects recruited was relatively small. Because symptoms of patients with a clinical (symptomatic) vertebral fracture might be easily changed by treatment, which could reduce the reproducibility of questionnaire, this study did not enroll these patients. Second, our subjects were osteopo- rosis or osteopenia patients, recruited at one spine center, and were a convenient sample, not randomly selected. Accordingly, generalizability of our quality of life scores is limited. Third, time between test and retest was relatively short which might have positively biased our reliability results.

\section{Conclusions}

The Korean version of ECOS-16 is the first conditionspecific outcome instrument for patients with osteoporosis or osteopenia to be validated in a Korean population. The development and validation of multiple-language versions of existing validated questionnaires plays a key role in standardizing outcome measurements and increasing the statistical powers of clinical studies. ECOS-16 was successfully translated into Korean and the psychometric properties of the original version were not lost. Accordingly, the Korean version of the ECOS-16 appears to be a reliable and valid outcome measure of functional status in Korean patients with osteoporosis or osteopenia. We recommend that this Korean version of the ECOS-16 be utilized for future clinical studies conducted in Korea.

\section{Conflict of Interest}

No potential conflict of interest relevant to this article was reported.

\section{Acknowledgments}

This work was supported for two years by Pusan National University Research Grant.

\section{References}

1. Randell A, Sambrook PN, Nguyen TV, et al. Direct clinical and welfare costs of osteoporotic fractures in elderly men and women. Osteoporos Int 1995;5:42732.

2. Cooper C, O’Neill T, Silman A. The epidemiology of vertebral fractures: European Vertebral Osteoporosis Study Group. Bone 1993;14 Suppl 1:S89-97.

3. Melton LJ 3rd. Epidemiology of spinal osteoporosis. Spine (Phila Pa 1976) 1997;22(24 Suppl):2S-11S.

4. Shin CS, Kim MJ, Shim SM, et al. The prevalence and risk factors of vertebral fractures in Korea. J Bone 
Miner Metab 2012;30:183-92.

5. Cook DJ, Guyatt GH, Adachi JD, et al. Development and validation of the mini-osteoporosis quality of life questionnaire (OQLQ) in osteoporotic women with back pain due to vertebral fractures. Osteoporosis Quality of Life Study Group. Osteoporos Int 1999;10:207-13.

6. Lau EM, Woo J, Chan H, et al. The health consequences of vertebral deformity in elderly Chinese men and women. Calcif Tissue Int 1998;63:1-4.

7. Lips P, Cooper C, Agnusdei D, et al. Quality of life in patients with vertebral fractures: validation of the Quality of Life Questionnaire of the European Foundation for Osteoporosis (QUALEFFO). Working Party for Quality of Life of the European Foundation for Osteoporosis. Osteoporos Int 1999;10:150-60.

8. Pluijm SM, Tromp AM, Smit JH, Deeg DJ, Lips P. Consequences of vertebral deformities in older men and women. J Bone Miner Res 2000;15:1564-72.

9. Ross PD. Clinical consequences of vertebral fractures. Am J Med 1997;103(2A):30S-42S.

10. Silverman SL. The clinical consequences of vertebral compression fracture. Bone 1992;13 Suppl 2:S27-31.

11. Kanis JA, Minne WH, Meunier PJ, Ziegler R, Allender E. Quality of life and vertebral osteoporosis. Osteoporos Int 1992;2:161-3.

12. Reginster JY, Compston JE, Jones EA, et al. Recommendations for the registration of new chemical entities used in the prevention and treatment of osteoporosis. Calcif Tissue Int 1995;57:247-50.

13. Hunt SM, McEwen J, McKenna SP. Measuring health status: a new tool for clinicians and epidemiologists. J R Coll Gen Pract 1985;35:185-8.
14. Bergner M, Bobbitt RA, Carter WB, Gilson BS. The Sickness Impact Profile: development and final revision of a health status measure. Med Care 1981;19:787-805.

15. Brazier JE, Harper R, Jones NM, et al. Validating the SF-36 health survey questionnaire: new outcome measure for primary care. BMJ 1992;305:160-4.

16. Measuring quality of life in women with osteoporosis. Osteoporosis Quality of Life Study Group. Osteoporos Int 1997;7:478-87.

17. Badia X, Prieto L, Roset M, Diez-Perez A, Herdman M. Development of a short osteoporosis quality of life questionnaire by equating items from two existing instruments. J Clin Epidemiol 2002;55:32-40.

18. Beaton DE, Bombardier C, Guillemin F, Ferraz MB. Guidelines for the process of cross-cultural adaptation of self-report measures. Spine (Phila Pa 1976) 2000;25:3186-91.

19. Han CW, Lee EJ, Iwaya T, Kataoka H, Kohzuki M. Development of the Korean version of ShortForm 36-Item Health Survey: health related QOL of healthy elderly people and elderly patients in Korea. Tohoku J Exp Med 2004;203:189-94.

20. Yilmaz F, Dogu B, Sahin F, Sahin T, Kuran B. Reliability and validity of the Turkish version of the ECOS 16 questionnaire in postmenopausal osteoporosis. Eur J Phys Rehabil Med 2009;45:521-6.

21. Salaffi F, Malavolta N, Cimmino MA, et al. Validity and reliability of the Italian version of the ECOS-16 questionnaire in postmenopausal women with prevalent vertebral fractures due to osteoporosis. Clin Exp Rheumatol 2007;25:390-403. 
Appendix 1. ECOS-16 Questionnaire

\section{ECOS-16 설문지}

\section{골다공증으로 인한 요통에 대한 지난주에 있었던 당신의 증상에 관한 설문입니다.}

1. 요통이 얼마나 자주 있었나요?

$\square$ 1. 전혀 없었다

$\square$ 2. 하루

3. 2-3일

$\square$ 4. 4-6일

5. 매일

2. 요통은 어느 정도로 심했습니까?

$\square$ 1. 전혀 없었다

$\square$ 2. 경도

$\square$ 3. 중증도

$\square$ 4. 고도

$\square$ 5. 참을 수 없는 정도

3. 장시간 서 있을 때 통증으로 얼마나 불편하셨습니까?

$\square$ 1. 거의 불편하지 않았다

$\square$ 2. 경미한 통증 및 불편감

3. 중증도의 통증 및 불편감

$\square$ 4. 심한 통증 및 불편감

$\square$ 5. 아주 심한 통증 및 불편감

4. 허리를 굽힐 때 어느 정도의 통증 및 불편감이 있었습니까?

$\square$ 1. 전혀 없었다

$\square$ 2. 경미한 통증 및 불편감

3. 중등도의 통증 및 불편감

4. 심한 통증 및 불편감

5. 아주 심한 통증 및 불편감
5. 요통으로 잠을 못 주무신 적이 있습니까?

1. 전혀 없었다

$\square$ 2. 하루

3. 이틀

4. 3-4일

5. 매일 밤

6. 집안일을 하는데 불편하십니까?

$\square$ 1. 불편하지 않음

2. 약간 불편함

3. 중등도 불편함

4. 매우 불편함

5. 아무것도 할 수가 없음

7. 계단 한 층을 올라갈 수 있습니까?

1. 불편 없이 가능함

2. 약간 불편함

3. 한번 이상 쉬어야 가능

4. 타인의 도움이 있어야 가능

5. 계단을 올라갈 수 없음

8. 옷을 입는데 불편함이 있습니까?

1. 불편하지 않음

2. 약간 불편함

3. 중등도 불편함

4. 가끔 도움이 필요함

5. 혼자서는 불가능함. 
9. 허리를 굽힐 때 불편함이 있습니까?

1. 불편하지 않음

$\square$ 2. 약간 불편함

$\square$ 3. 중등도 불편함

$\square$ 4. 아주 불편함

5. 허리를 굽힐 수 없음

10. 보행시 불편함이 있습니까?

1. 불편하지 않음

2. 약간 불편함

3. 중등도 불편함

4. 아주 불편함

5. 보행이 안됨

11. 친구나 친지를 방문하는데 불편함이 있습니까?

$\square$ 1. 불편하지 않음

$\square$ 2. 약간 불편함

3. 중등도 불편함

4. 아주 불편함

5. 친구나 친지를 방문할 수 없음

12. 기운이 없고 귀찮음을 느끼십니까?

$\square$ 1. 전혀 그렇지 않음

2. 드물게

3. 가끔

4. 자주

5. 항상
13. 당신의 미래를 희망적으로 생각하십니까?

1. 항상

2. 자주

3. 가끔

$\square$ 4. 드물게

5. 전혀 그렇지 않음

14. 좌절감을 느낍니까?

1. 전혀 그렇지 않음

2. 드물게

3. 가끔

4. 자주

5. 항상

15. 넘어지는 것에 대한 두려움을 느낍니까?

$\square$ 1. 전혀 그렇지 않음

$\square$ 2. 드물게

$\square$ 3. 가끔

4. 자주

5. 항상

16. 골절이 생길 것에 대한 두려움을 느낍니까?

$\square$ 1. 전혀 그렇지 않음

2. 드물게

3. 가끔

4. 자주

5. 항상 